

Renewables

Sustainability

Environmental Monitoring

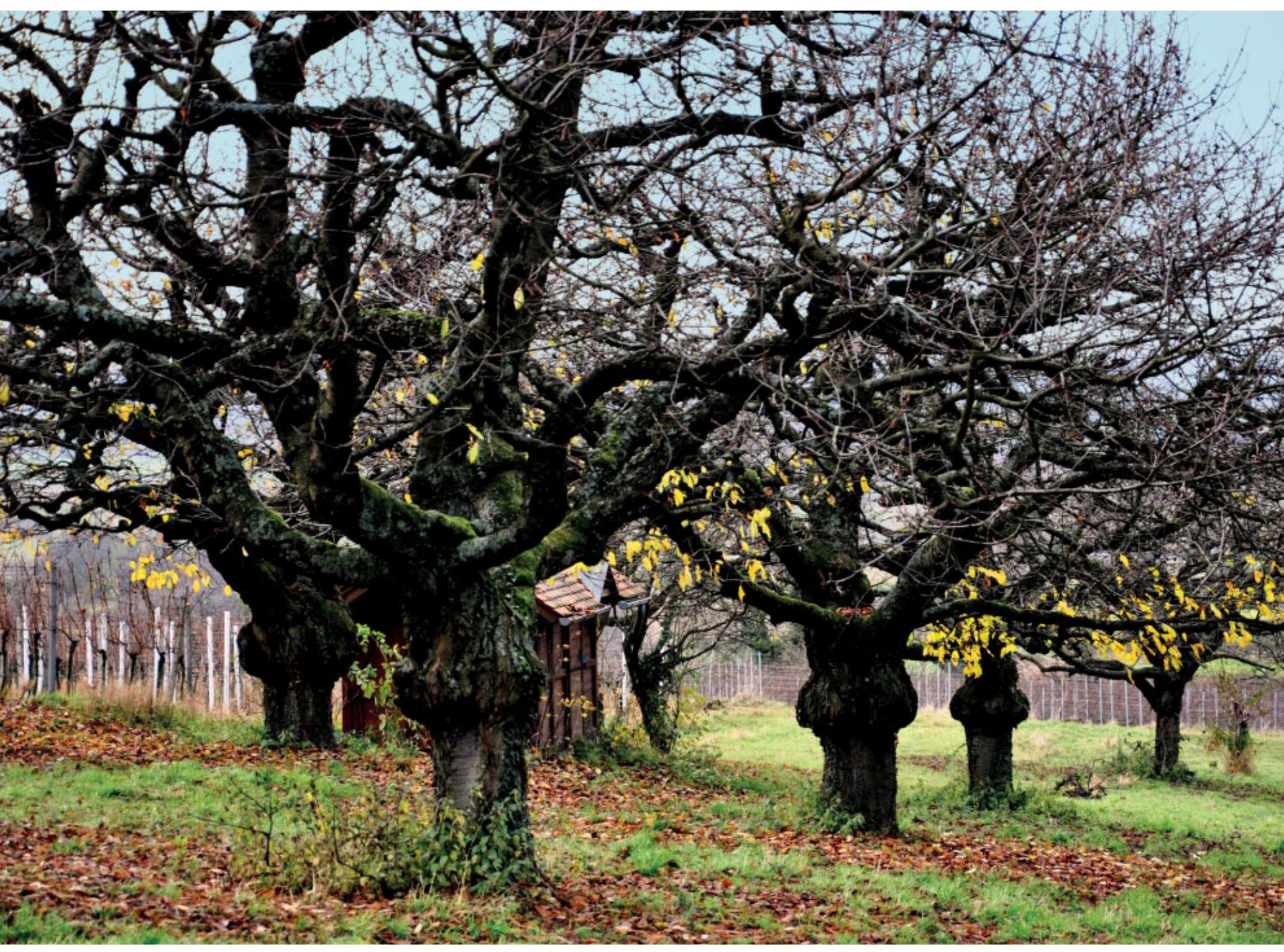




\author{
Xing Sun ${ }^{\star 1,2}$ \\ Gengmao Zhao' \\ Chenhao $\mathrm{Gu}^{\star 3}$ \\ Ling Liu* \\ Ming $\mathrm{Zhu}^{4}$ \\ Zhaopu Liu ${ }^{1}$ \\ 1Jiangsu Key Laboratory of Marine \\ Biology, College of Resources and \\ Environmental Sciences, Nanjing \\ Agricultural University, Nanjing \\ Jiangsu Province, Nanjing, P. R. \\ China \\ ${ }^{2}$ Key Laboratory of Coastal Zone \\ Environmental Processes, Yantai \\ Institute of Coastal Zone Research \\ (YIC), Chinese Academy of Sciences \\ (CAS); Shandong Provincial Key \\ Laboratory of Coastal Zone \\ Environmental Processes, YICCAS, \\ Yantai Shandong, P. R. China \\ ${ }^{3}$ College of life Science, Nanjing \\ Agricultural University, Nanjing \\ Jiangsu Province, Nanjing, P. R. \\ China \\ ${ }^{4}$ Jiangsu Key Laboratory of Marine \\ Biotechnology, Huai Hai Institute of \\ Technology, Lianyungang Jiangsu \\ Province, Lianyungang, P. R. China
}

Research Article

\section{Screening for and Identification of an Anti-clam Vibrio Marine Bacterium from an Aquaculture Pond in the Yellow Sea}

The identification and use of probiotic bacterial stains is a practical approach to protect clams grown in aquaculture farms from disease. The inhibition of the pathogenic bacterium Vibrio alginolyticus was used as a trait to select a candidate probiotic bacterial strain in this study. An ideal bacterial strain, SW-1, was isolated from seawater from a clam farm. The selected isolate SW-1 was identified based on its physiological, morphological, and biochemical characteristics and its $16 \mathrm{~S}$ rDNA sequence. The experiments showed that strain SW-1 had a high similarity to Pseudoalteromonas piscicida and could inhibit the growth of $V$. alginolyticus (V.-MP-1). SW-1 also improved the survival of clams following challenge with the pathogenic $V$-MP-1. The mortality of clams was $100 \%$ after infection with $10^{8} \mathrm{CFU} / \mathrm{mL}$ of $V$. alginolyticus, whereas mortality was only $11 \%$ when clams were infected with $10^{8} \mathrm{CFU} / \mathrm{mL}$ of $\mathrm{V}$.-MP1 while simultaneously exposed to the same concentration of Pseudoalteromonas SW-1, indicating that Pseudoalteromonas SW-1 could be used as a probiotic to protect farmed clams, and thus reduce the effects of antibiotics on aquatic environment.

Keywords: Fish disease; Meretrix meretrix, Probiotic; 16S rDNA

Received: October 2, 2012; revised: October 2, 2012; accepted: October 16, 2012

DOI: $10.1002 /$ clen.201200478

\section{Introduction}

Aquaculture production is valued at US\$98.4 billion and accounts for $35.7 \%$ of aquatic production worldwide [1]. In the case of China, the total level of domestic aquatic production has been reported to be over 47.5 million tons, which accounts for $62 \%$ of global production in terms of quantity and $51 \%$ of global value in 2008 . Meretrix meretrix (Linnaeus) is one of the main shellfish varieties that is grown along the southeast coast of China. In Jiangsu Province, for example, M. meretrix production in 2008 was approximately 0.06 million tons, with an estimated first-sale value of US\$ 62.6 million, representing nearly a half of the country's total [2]. Disease outbreaks caused by pathogenic bacteria, commonly of the genus Vibrio, are a major cause of mortality in shellfish larvi-culture and can result in financial losses for commercial growers [3]. A variety of antibiotics have been used for the prevention of diseases, but the overuse of antibiotics can lead to the emergence of resistant bacteria and environmental problems [4-6], such as: the abuse of antibiotics may remain in high concentration in aquatic products and in surface water, resulting in the high risk of these chemical to human health and the environment $[7,8]$. Therefore, alternatives to antibiotics, such as functional foodstuff or natural antimicrobial materials, are needed.

Correspondence: Professor G. M. Zhao, Jiangsu Key Laboratory of Marine Biology, College of Resources and Environmental Sciences, Nanjing Agricultural University, Nanjing Jiangsu Province 1 Tongwei Road, Nanjing, 210095, P. R. China

E-mail: zhaogengmao@126.com

Abbreviations: CFU, colony-forming unit; MB, marine broth; P.SW-1, Pseudoalteromonas SW-1; V.-MP-1, Vibrio MP-1.
The term "probiotics" traditionally refers to live microbial feed supplements that beneficially affect the host animal by improving its intestinal microbial balance [9-11]. Recently, the interest in the use of probiotics in aquaculture has increased. In particular, a variety of in vivo and in vitro studies on the positive effect of using probiotics on fish, shrimp, and molluscs have been performed [12-14]. Currently, a number of preparations of probiotics, such as lactic acid bacteria, are commercially available. According to the claims of the producers, these products are effective in supporting the health of aquatic animals and are safe.

There are a few reports on the use of probiotic bacteria relevant to the prevention of shellfish diseases, both in China and abroad. The objective of this study was to screen for and identify anti-clam Vibrio bacteria and then to provide a basis for the exploitation of probiotic products for sustainably developing aquaculture [15-17].

\section{Materials and methods}

\subsection{Isolates of Pseudoalteromonas SW-1 (P.-SW-1)}

Water samples were collected from M. meretrix farms located in Qidong County, Jiangsu, China (lat. $30^{\circ} 45^{\prime} 36 \mathrm{~N}$ and long. $\left.120^{\circ} 21^{\prime} 4 \mathrm{E}\right)$. To isolate P.-SW-1, aliquots $(0.1 \mathrm{~mL})$ of diluted $\left(10^{-1}\right)$ water samples were spread onto ZoBell's Marine Agar plates (composition: $1 \mathrm{~g}$ yeast extract, $5 \mathrm{~g}$ peptone, $0.1 \mathrm{~g} \mathrm{FePO}_{4}, 20 \mathrm{~g}$ agar, $1000 \mathrm{~mL}$ seawater, $\mathrm{pH}$ 8.0). The plates were incubated at $30^{\circ} \mathrm{C}$ for $48 \mathrm{~h}$, and then the colonies were purified by plate streak methods. Colonies

*These authors contributed equally to this work.

Additional correspondence: Professor Z. P. Liu, e-mail: seawater@njau.edu.cn. 
causing inhibition of Vibrio MP-1 (V.-MP-1) were isolated [15] and pure cultured. Isolates were frozen at $-70^{\circ} \mathrm{C}$ in marine broth $(50 \%$; $\mathrm{MB}$ diluted $1: 1$ with sterile seawater) containing $30 \%$ glycerol. The best activity strain was identified based on their morphological and physiological characteristics. The morphological, physiological, and biochemical characteristics were similar to the species of Pseudoalteromonas.

\subsection{Pathogen isolate (V.-MP-1)}

A pathogen causing clam disease (Vibrio alginolyticus) was isolated from diseased clams that had been collected at the Qidong Yellow Sea Breeding, in 2009. These clams were peeled off and ground, diluted tenfold with sterilized water, and then placed on ZoBell's Marine Agar plates. The plates were incubated at $28^{\circ} \mathrm{C}$ for three days. The colonies from the sample tissues were then incubated on TCBS agar plates. After two days, yellow and blue strains were removed and purified. The colonies were purified and identified based on their morphological and physiological characteristics and partial 16S rDNA gene sequence analyses. The results showed that the colonies were similar to V. alginolyticus [16] (GenBank accession no. JX046039). The virulence tests showed that the strain V.-MP-1 was the clam pathogenic bacteria. Isolates were frozen at $-70^{\circ} \mathrm{C}$ in marine broth $(50 \%$; MB diluted $1: 1$ with sterile seawater) containing $30 \%$ glycerol. Working strains were stored on ZoBell's Marine Agar slants at $4^{\circ} \mathrm{C}$.

\subsection{Identification of strain SW-1 by phylogenetic analysis}

DNA from bacterial isolates cultured in Luria-Bertani (LB) broth was extracted by $1 \mathrm{~mL}$ of culture by centrifugation. The total DNA was extracted using a DNA extraction kit according to the manufacturer's instructions (Genetech, China). 16S rDNA was amplified with the universal primers $27 f\left(5^{\prime}\right.$-AGAGTTTGATCCTGGCTCAG-3') and 1492r (5'-GGTTACCTTGTTACGACTT- $\left.{ }^{\prime}\right)$. The PCR amplification was performed as follows: one cycle of $5 \mathrm{~min}$ at $95^{\circ} \mathrm{C}, 40 \mathrm{~s}$ at $94^{\circ} \mathrm{C}, 30 \mathrm{~s}$ at $58^{\circ} \mathrm{C}$, and $1.5 \mathrm{~min}$ at $70^{\circ} \mathrm{C}$, followed by 30 cycles of $8 \mathrm{~min}$ each at $72^{\circ} \mathrm{C}$. The PCR products were purified and sequenced by Invitrogen Corporation in Shanghai. DNA sequence homology searches were performed using the online BLAST search engine in GenBank at the National Center for Biotechnology Information (NCBI). The phylogenetic tree for the data set was constructed using the neighbor-joining method with MEGA version 4.0.2.

\subsection{Optimal temperature, $\mathrm{pH}$ and salinity for the growth of $P$.-SW-1}

The optimal conditions for the growth of P.-SW-1 were determined by growing the bacterium in ZoBell's MB at various temperatures (25, 30,35 , and $\left.37^{\circ} \mathrm{C}\right), \mathrm{pH}(5.0,6.0,7.0,8.0$, and 9.0$)$, and salinities $(0.2,0.5$, $0.8,1.0$, and $1.5 \mathrm{~mol} / \mathrm{L}$ ) using a $1 \%$ inoculum (cultures concentration in ZoBell's MB medium to approximately $10^{6}$ coloniy-forming unit (CFU)/mL after inoculation). These cultures were incubated for $24 \mathrm{~h}$ in duplicate. The absorbance (a measure of growth) was measured with a 722 spectrophotometer at a wavelength of $600 \mathrm{~nm}$.

\subsection{Growth characteristics of P.-SW-1}

Pure colonies of P.-SW-1 were transferred to a hard glass tube containing $5 \mathrm{~mL}$ of ZoBell's MB and incubated $24 \mathrm{~h}$ at $30^{\circ} \mathrm{C}$. Then, these cultures were used to inoculate Erlenmeyer flasks containing ZoBell's $\mathrm{MB}$, and the flasks were incubated on a rotatory shaker $(180 \mathrm{rpm})$ at $30^{\circ} \mathrm{C}$. The growth of P.-SW-1 was measured at $600 \mathrm{~nm}$ at regular intervals $(0,2,4,6,8,10,12,14,16,18,20,22,24,26,28,30$, and $32 \mathrm{~h}$ ). The absorbance measurement of the sterile ZoBell's MB was used as the blank measurement for each respective well.

\subsection{Antibacterial testing}

The antibacterial activity of P.-SW-1 was evaluated by the paper-disk agar diffusion method against different strains. Vibrio alginolyticus (GenBank accession no. JX046039) was isolated from the clam farming in China. Achromobacter sp. YZ (GenBank accession no. EF617310), and Bacillus J1 (GenBank accession no. FJ815201) were obtained from Nanjing Agricultural University and Jiangsu Key Laboratory of Marine Biology. Inocula were prepared by diluting overnight $(24 \mathrm{~h}$ at $30^{\circ} \mathrm{C}$ ) cultures in ZoBell's MB medium to approximately $10^{6} \mathrm{CFU} /$ $\mathrm{mL}$. Absorbent disks (Whatman, diameter $6 \mathrm{~mm}$ ) were impregnated with P.-SW-1. The diameters of the growth inhibition zones were measured after incubation at $30^{\circ} \mathrm{C}$ for $24 \mathrm{~h}$. The experiment was performed in quadruplicate.

\subsection{Virulence tests}

The possible probiotic P.-SW-1 and the pathogenic strain V.-MP-1 were tested in experimental clam infections. All inocula were prepared by diluting overnight $\left(24 \mathrm{~h}\right.$ at $\left.30^{\circ} \mathrm{C}\right)$ cultures in ZoBell's MB medium to approximately $10^{7}, 10^{8}$, or $10^{9} \mathrm{CFU} / \mathrm{mL}$. Each group of 15 clams was randomly allocated in 25-L fiberglass tanks, and these inocula were poured into the tanks in triplicates. Survival was monitored for 15 days.

\section{Results and discussions}

\subsection{Bacterial isolates}

The strain with the best inhibitory activity, SW-1, grew on ZoBell's $\mathrm{MB}$ in the form of sub-round, straw yellow colonies. This bacterium was found to be a Gram-negative aerobic heterotrophic prokaryote that is widely distributed in the marine environment. The dimensions of the bacterium were $0.6-0.9 \mu \mathrm{m}$. The physiological and biochemical characteristics of strain SW-1 are shown in Table 1. Some characteristics of the SW-1 strain were identical to those previously reported for $P$. piscicida $[17,18]$.

\subsection{Identification of the strain SW-1 by phylogenetic analysis}

The 16S rDNA of strain SW-1 was amplified with primers $27 \mathrm{f}$ and 1492r. The genomic DNA is shown in Fig. 1. The almost-complete $16 \mathrm{~S}$ rDNA gene sequence (1398 bp) of strain SW-1 was determined, and this sequence was submitted to GenBank (GenBank accession no. JX046040). The analysis of the $16 \mathrm{~S}$ rDNA sequence indicated that the strain shared 99\% identity with Pseudoalteromonas. In addition, a neighbor-joining tree (Fig. 2) clearly demonstrated that strain SW1 was a member of Pseudoalteromonas at the 16S rDNA sequence homology level. It was therefore evident from the phylogenetic data that stain SW-1 represented a species of the genus Pseudoalteromonas. 
Table 1. The physiological and biochemical characteristics of strain SW-1 in comparison with those of $P$. piscicida

\begin{tabular}{|c|c|c|}
\hline Item & $\begin{array}{l}\text { Strain } S W-1 \\
\text { response }\end{array}$ & $\begin{array}{l}\text { P. piscicida }{ }^{\text {a) }} \\
\text { response }\end{array}$ \\
\hline \multicolumn{3}{|l|}{ Growth at } \\
\hline $4^{\circ} \mathrm{C}$ & + & + \\
\hline $30^{\circ} \mathrm{C}$ & + & + \\
\hline $35^{\circ} \mathrm{C}$ & + & + \\
\hline $40^{\circ} \mathrm{C}$ & - & - \\
\hline Gram stain & - & - \\
\hline Straight rod & + & + \\
\hline Motility & + & + \\
\hline Polar flagella & + & + \\
\hline Colony pigment & $\begin{array}{l}\text { Yellow, insoluble } \\
\text { in water }\end{array}$ & $\begin{array}{c}\text { Yellow, insoluble } \\
\text { in water }\end{array}$ \\
\hline Oxidase & + & + \\
\hline Gelatinase & + & - \\
\hline Requires $\mathrm{NaCl}$ for growth & + & + \\
\hline \multicolumn{3}{|l|}{ Utilization of } \\
\hline D-Glucose & + & + \\
\hline Sucrose & - & - \\
\hline Citrate & - & + \\
\hline Lactose & - & - \\
\hline M.R. reaction & - & - \\
\hline Voges-Proskauer test & - & - \\
\hline Indole production & - & - \\
\hline $\mathrm{H}_{2} \mathrm{~S}$ production & + & - \\
\hline Amylase & - & - \\
\hline
\end{tabular}

+ , positive; - , negative.

a) Ivanova et al. [17] and Longeon et al. [18].

\subsection{Optimal temperature, $\mathrm{pH}$ and salinity for the promotion of antagonistic action by $P$.-SW-1}

According to the analysis of bacterial biomass, expressed as the absorbance at $600 \mathrm{~nm}\left(\mathrm{OD}_{600}\right)$ (Fig. 3), strain SW-1 could grow at temperatures from 25 to $37^{\circ} \mathrm{C}$ (Fig. 3A). The highest biomass $\left(\mathrm{OD}_{600}=0.68\right)$ was observed at $30^{\circ} \mathrm{C}$. Within the temperature range of 25 to $30^{\circ} \mathrm{C}$, the biomass increased with increasing temperature. When the temperature exceeded $30^{\circ} \mathrm{C}$, the biomass decreased.

The effect of the $\mathrm{NaCl}$ concentration in the growth media is presented in Fig. 3B. ZoBell's $\mathrm{MB}$ containing $0.5 \mathrm{~mol} / \mathrm{L} \mathrm{NaCl}$ was optimum for growth, followed by ZoBell's MB containing $0.8 \mathrm{~mol} /$ $\mathrm{L} \mathrm{NaCl}$. Minimal growth was observed in ZoBell's MB containing $1.5 \mathrm{~mol} / \mathrm{L} \mathrm{NaCl}$.

The pH range supporting the growth of strain SW-1 was 6.0-9.0. The highest biomass $\left(\mathrm{OD}_{600}=0.80\right)$ was observed at $\mathrm{pH} 8.0$, and at $\mathrm{pH}$



Figure 1. $M$ is the marker, and $A$ is the genomic DNA of strain SW-1.

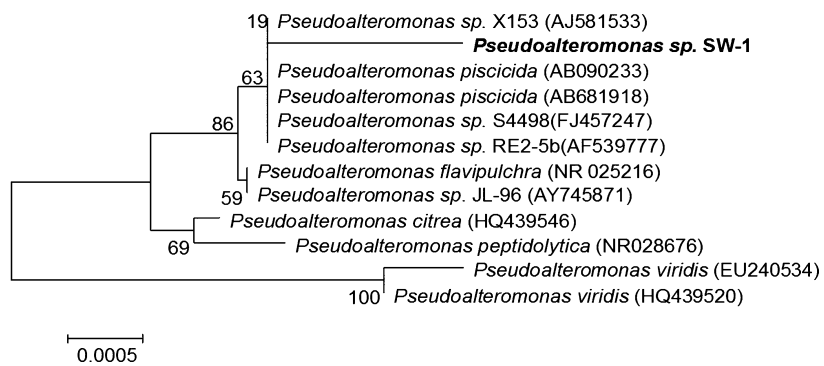

Figure 2. Phylogenetic tree based on comparison of the 16S rRNA gene sequences to determine the position of strain SW-1. The phylogenetic tree was generated using the neighbor-joining method. Bootstrap values, expressed as percentages of 1000 replications, are given at the branch points.

5.0, there was no growth at all (Fig. 3C). At $\mathrm{pH}>8.0$, the biomass decreased.

\subsection{Growth characteristics of $P$.-SW-1}

The resulting growth curves showed that in the range of $0-4 \mathrm{~h}$, the absorbance at $600 \mathrm{~nm}$ of P.SW-1 remained low (i.e., the bacterium was in the lag phase), and between 6 and $20 \mathrm{~h}$, the biomass of P.-SW-1
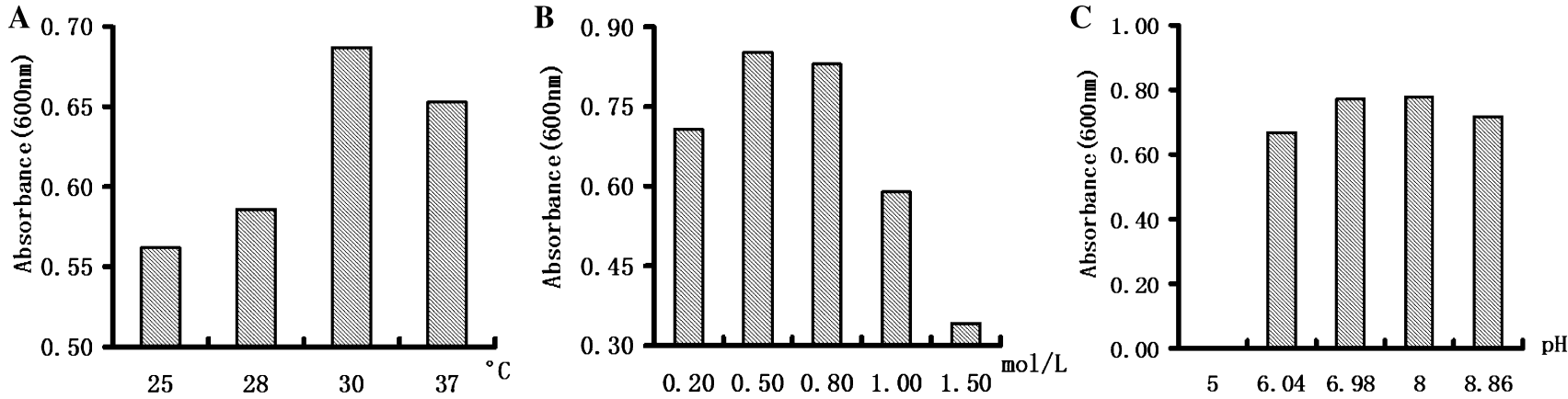

Figure 3. Effects of culture conditions (A, incubation temperature; B, incubation salinity; $\mathrm{C}$, incubation pH) on the biomass of strain SW-1. 


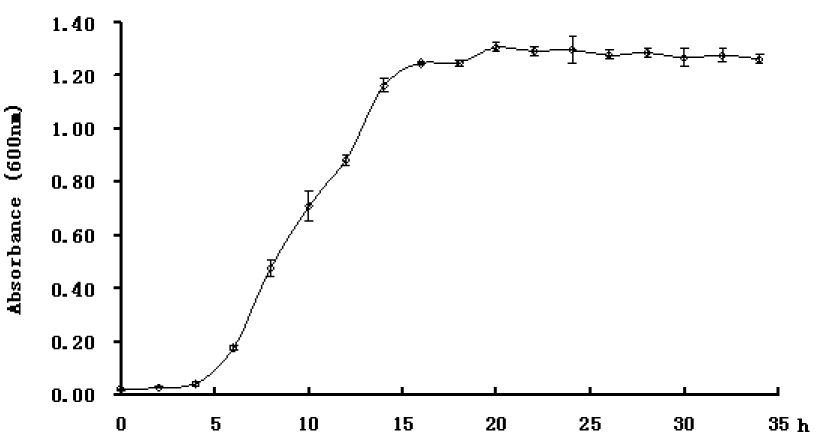

Figure 4. Growth curves for strain SW-1.

rapidly increased (logarithmic phase; Fig. 4). After $20 \mathrm{~h}$, the biomass of the P.-SW-1 was stable.

\subsection{Antibacterial testing}

Strain P.SW-1 showed good inhibition of $V$. alginolyticus, Achromobacter sp. YZ, and Bacillus J1 in paper-disk agar diffusion assay. The zone of inhibition was between 16 and $20 \mathrm{~mm}$ (Table 2).

\subsection{Virulence tests}

Virulence tests showed that the isolated strain P.-SW-1 was not pathogenic to clams. Over the 15-day test, the mortality of clams was zero, compared with $30 \%$ mortality in the control group (Table 3). Clams infected with $10^{7}-10^{9} \mathrm{CFU} / \mathrm{mL}$ of $V$.-MP-1 exhibited mortality of $100 \%$. In contrast, clams infected simultaneously with $10^{8} \mathrm{CFU} / \mathrm{mL}$ of $V .-\mathrm{MP}-1$ and P.-SW-1 exhibited an average mortality of only $11 \%$.

Along the coast of the Yellow Sea in China, M. meretrix has become one of the most important commercial marine bivalves [2]. In the 1990s, mass mortality of M. meretrix due to unknown causes was reported [19]. Later, the Vibrios bacteria were identified as a major reason for the mass mortality of M. meretrix. However, the usages of antibiotics can cause water pollution, and indirectly affect human health [20]. So, Utilization of microorganisms is a very effective way to resist the pathogen hazards.

In this study, P.-SW-1 was isolated from seawater from a clam farm. The isolated P.-SW-1 strain was identified by morphological, physio-

Table 2. The zone of inhibition of P.-SW-1 for different strains

\begin{tabular}{lcc}
\hline Strain & $\begin{array}{c}\text { Zone of } \\
\text { inhibition }(\mathrm{mm})\end{array}$ & $\begin{array}{c}\text { Average zone of } \\
\text { inhibition }(\mathrm{mm})\end{array}$ \\
\hline Vibrio alginolyticus & 17 & 16.7 \\
& 16 & \\
Achromobacter sp. YZ & 18 & 17.3 \\
& 16 & \\
& 18 & 19 \\
Bacillus J1 & 17 & \\
& 18 & \\
& 16 & \\
& 19 & \\
& 20 & \\
& 19 & \\
\end{tabular}

Table 3. Mortality of clams in virulence tests with different amounts of P.-SW-1 and V.-MP-1

\begin{tabular}{lcc}
\hline Bacterial species & $\begin{array}{c}\text { Inoculating dose } \\
(\mathrm{CFU} / \mathrm{mL})\end{array}$ & $\begin{array}{c}\text { Survivors/total } \\
(15 \text { days })\end{array}$ \\
\hline Control & 0 & $13 / 15$ \\
V.-MP-1 & $10^{7}$ & $0 / 15$ \\
& $10^{8}$ & $0 / 15$ \\
P.-SW-1 & $10^{9}$ & $0 / 15$ \\
& $10^{7}$ & $15 / 15$ \\
V.-MP-1 and P.-SW-1 & $10^{8}$ & $15 / 15$ \\
& $10^{9}$ & $15 / 15$ \\
& $10^{8}$ & $14 / 15$ \\
& & $14 / 15$ \\
\end{tabular}

logical, and biochemical assays (Table 1), but these assays alone are never sufficient to confirm the taxonomic status. As suggested by Garrity et al. [21], 16S rDNA sequencing is the only alternative method for conclusive identification. Based on the partial $16 \mathrm{~S}$ rDNA sequences and phylogenetic analysis using the neighbor-joining method, SW-1 is a member of the genus Pseudoalteromonas and is closely related to $P$. piscicida, Pseudoalteromonas sp. X153 and Pseudoalteromonas sp. S4498 (Fig. 2). This result clearly indicated that the SW-1 is very closely related to a strain Pseudoalteromonas sp. X153, which was isolated from a pebble collected at St. Anne du Portzic (France) and was found to be highly active against ichthyopathogenic Vibrio strains [18]. Therefore, strain SW-1 is a bacterial strain belonging to the species $P$. piscicida, a conclusion that is consistent with the results of the morphological and physiological assays.

The results presented in Table 2 indicate that P.-SW-1 could inhibit not only the Vibrio bacteria that are pathogenic to clams but also other strains, such as Achromobacter sp. YZ and Bacillus J1. Many studies have confirmed that species of Pseudoalteromonas display antagonistic activities against a variety of target organisms [18, $22,23]$.

The antibacterial testing results showed that the P.-SW-1 isolate from the aquaculture farm caused a wide range of resistance to several strains tested. The data in Table 3 clearly show that P.-SW-1 was non-pathogenic to clams even at a very high level of $10^{9}$ cells $/ \mathrm{mL}$. After infection with P.-SW-1 for 15 days, clams exhibited improved survival following challenge with pathogenic bacteria (V.-MP-1). Robertson et al. [24] found that the administration of a single probiotic or a mixture of the three probiotics for 14 days resulted in increased levels of survival after challenge. The use of other strains as probiotics for protection against bacterial pathogens among fishes is well documented [25-28]. Thus, we believe that P.-SW-1 is a promising probiotic that can be used to treat farmed clams whenever V.-MP-1 counts rise to undesirable levels in aquaculture systems.

Additionally, virulence tests showed that the isolated strain P.-SW1 was not pathogenic to clams, suggesting that P.-SW-1 could be safely used in aquatic farms to improve the survival of clams and the aquaculture environment.

\section{Concluding remarks}

It can be stated that the P.-SW-1 strain has the properties of a biocontrol agent for use in clam culture farms. There is also a potential to use this strain for the control of Vibrio spp. in aquaculture systems and maintain the clam aquaculture sustainable development in the future. 


\section{Acknowledgments}

This work was supported by a grant from the Research Fund of Jiangsu Key Laboratory of Marine Biotechnology (NO. 2008HS020). This study was part of the PhD studies of Mrs. Xing Sun funded by Prof. Zhaopu Liu. We would like to thank Zhiguo Dong for his assistance during the sampling of cod rearing systems, Xianfa Meng for the preparation of PCR products for taxonomic identification, Mingxiang Liang for the 16S rRNA partial sequencing analysis and Xiumei Gao for laboratory assistance.

The authors have declared no conflict of interest.

\section{References}

[1] FAO Fisheries and Aquaculture Department, Food and Agriculture Organization of the United Nations, Rome 2010.

[2] X. C. Song, X. H. Wan, G. X. Yao, A. H. Chen, Analyse of the Occurrence Mechanism and Controlling of Eruptive Epidemic Disease of Meretrix meretrix in Jiangsu Coast, J. Aquacult. 2007, 28, 38-41.

[3] R. M. Estes, C. S. Friedman, R. A. Elston, Pathogenicity Testing of Shellfish Hatchery Bacterial Isolates on Pacific Oyster Crassostrea gigas Larvae, Dis. Aquat. Org. 2004, 58, 223-230.

[4] C. H. Yen, K. F. Chen, Y. T. Sheu, C. C. Lin, J. J. Hong, Pollution Source Investigation and Water Quality Management in the Carp Lake Watershed, Taiwan, Clean - Soil Air Water 2012, 40, 24-33.

[5] D. P. Weston, Environmental Considerations in the Use of Antibacterial Drugs in Aquaculture (Eds.: D. Baird, M. V. M. Beveridge, L. A. Kelly, J. F. Muir), Blackwell, Oxford 1996, pp. 140-165.

[6] I. Karunasagar, R. Pai, G. R. Malathi, I. Karunasagar, Mass Mortality of Penaeus monodon Larvae due to Antibiotic Resistant Vibrio harveyi Infection, Aquaculture 1994, 128, 203-209.

[7] P. T. Thuy, N. V. Anh, B. van der Bruggen, Evaluation of Two Low-Cost-High-Performance Adsorbent Materials in the Waste-toProduct Approach for the Removal of Pesticides from Drinking Water, Clean - Soil Air Water 2012, 40, 246-253.

[8] J.Zolgharnein, A. Shahmoradi, J. Ghasemi, Pesticides Removal Using Conventional and Low-Cost Adsorbents: A Review, Clean - Soil Air Water 2011, 39, 1105-1119.

[9] R. Fuller, Probiotics in Man and Animals, J. Appl. Bacteriol. 1989, 66, 365-378.

[10] F. J. Gatesoupe, The Use of Probiotics in Aquaculture, Aquaculture 1999, 180, 147-165.

[11] L. Gram, J. Melchiorsen, B. Spanggaard, I. Huber, T. F. Nielsen, Inhibition of Vibrio anguillarum by Pseudomonas fluorescens AH2, a Possible Probiotic Treatment of Fish, Appl. Environ. Microbiol. 1999, 65, 969-973.

[12] O. P. Sharma, S. K. S. Bhukhar, Effect of Aquazyn-TM-1000, a Probiotic on the Water Quality and Growth of Cyprinus carpio var. communis, Ind. J. Fish. 2000, 47, 209-213.
[13] A. Irianto, B. Austin, Use of Probiotics to Control Furunculosis in Rainbow Trout, Oncorhynchus mykiss (Walbaum), J. Fish Dis. 2002, 25, 333-342.

[14] N. G. Vine, W. D. Leukes, H. Kaiser, Probiotics in Marine Larviculture, FEMS Microbiol. Rev. 2006, 30, 404-427.

[15] M. Hjelm, O. Bergh, A. Riaza, J. Nielsen, J. Melchiorsen, S. Jensen, H. Duncan, et al. Selection and Identification of Autochthonous Potential Probiotic Bacteria from Turbot Larvae (Scophthalmus maximus) Rearing Units, Syst. Appl. Microbiol. 2004, 27, 360-371.

[16] X. Sun, G. M. Zhao, Z. P. Liu, W. Z. Li, H. M. Luo, Screening and Identification of a Clam Vibrio, J. Aquacult. 2011, 32, 33-35.

[17] E. P. Ivanova, L. S. Shevchenko, T. Sawabe, A. M. Lysenko, V. I. Svetashev, N. M. Gorshkova, M. Satomi, et al. Pseudoalteromonas maricaloris sp. Nov., Isolated from an Australian sponge, and Reclassification of [Pseudoalteromonas aurantia] NCIMB 2033 as Pseudoalteromonas flavipulchra sp. Nov, Int. J. Syst. Evol. Microb. 2002, 52, 263-271.

[18] A. Longeon, J. Peduzzi, M. Barthelemy, S. Corre, J. L. Nicolas, M. Guyot, Purification and Partial Identification of Novel Antimicrobial Protein from Marine Bacterium Pseudoalteromonas Species Strain X153, Mar. Biotechnol. 2004, 6, 633-641.

[19] X. H. Ding, L. X. Ye, The Generation and Measures of "Marine Sudong" Green Development Strategy, J. Nanjing. Agric. Univ. 2003, 4, 25-32.

[20] E. Caylak, Health Risk Assessment for Arsenic in Water Sources of Cankiri Province of Turkey, Clean - Soil Air Water 2012, 40, 728-734.

[21] G. M. Garrity, D. J. Brenner, N. R. Krieg, J. T. Staley, Bergey's Manual of Systematic Bacteriology: The Proteobacteria, Part B, The Gammaproteobacteria, 2nd ed., Vol. 2, Springer, New York, USA 2005, p. 1103.

[22] C. Lovejoy, J. P. Bowman, G. M. Hallegraeff, Algicidal Effects of a Novel Marine Pseudoalteromonas Isolate (class Proteobacteria, gamma subdivision) on Harmful Algal Bloom Species of the Genera Chattonella, Gymnodinium and Heterosigma, Appl. Environ. Microbiol. 1998, 64, 2806-2813.

[23] S. Lee, J. Kato, N. Taliguchi, A. Kuroda, T. Ikeda, T. Mitsutani, H. Ohtake, Involvement of an Extracellular Protease in Algicidal Activity of the Marine Bacterium Pseudoalteromonas sp. Strain A28, Appl. Environ. Microbiol. 2000, 66, 4334-4339.

[24] P. A. W. Robertson, C. O'Dowd, C. Burrells, P. Williams, B. Austin, Use of Carnobacterium sp. as Probiotic for Atlantic Salmon (Salmo salar L.) and Rainbow Trout (Oncorhynchus mykiss, Walbaum), Aquaculture 2000, 185, 235-243.

[25] D. J. W. Moriarty, Control of Luminous Vibrio Species in Penaeid Aquaculture Ponds, Aquaculture 1998, 164, 351-358.

[26] H. Sugita, Y. Hirose, N. Matsuo, Y. Deguchi, Production of the Antibacterial Substance by Bacillus Species Strain NM12, an Intestinal Bacterium of Japanese Coastal Fish, Aquaculture 1998, 165, 269-280

[27] B. Gomez-Gil, A. Roque, J. F. Turnbull, The Use and Selection of Probiotic Bacteria for Use in the Culture of Larval Aquatic Organisms, Aquaculture 2000, 191, 259-270.

[28] M. Gullian, F. Thompson, J. Rodriguez, Selection of Probiotic Bacteria and Study of their Immunostimulatory Effect in Penaeus vannamei, Aquaculture 2004, 233, 1-14. 